Mini Review

\title{
Screen Printed Electrodes in Biosensors and Bioassays. A Review
}

\section{Miroslav Pohanka}

Faculty of Military Health Sciences, University of Defence, Trebesska 1575, CZ-500 01 Hradec

Kralove, Czech Republic

E-mail: miroslav.pohanka@gmail.com

doi: $10.20964 / 2020.11 .19$

Received: 9 July 2020 / Accepted: 31 July 2020 / Published: 30 September 2020

Screen-printed electrodes and screen-printed electrochemical sensors (devices containing more electrodes on the same printed platform) are a promising tool in for the construction of portable analytical devices. Various biosensors and bioassays are connected with the screen-printed electrodes respective electrochemical sensors outcoming from the electrodes. The glucose biosensors containing glucose oxidase, devices also called personal glucometers, are the most commercially relevant biosensors based on screen printed electrodes. Nevertheless, the research on this issue is resuming and new devices having practical impact can be expected in the future. This review summarizes basic data about biosensors and similar bioanalytical devices, provides overview of actual literature and disses practical relevance of the methods. Recent papers are cited in this review article.

Keywords: 3D printing; amperometry; assay; bioassay; biosensor; carbon; electrode; gold; print; voltammetry

\section{$\underline{\text { FULL TEXT }}$}

(C) 2020 The Authors. Published by ESG (www.electrochemsci.org). This article is an open access article distributed under the terms and conditions of the Creative Commons Attribution license (http://creativecommons.org/licenses/by/4.0/). 